\title{
Sixweeks Fescue As A Deterrent To Blue Grama Utilization ${ }^{1}$
}

\section{N. HYDER AND R. E. BEMENT}

Research Agronomist and Research Range Conservationist, Crops Research Division, Agricultural Research Service, U. S. Department of Agriculture, Fort Collins, Colorado.

\section{Highlight}

Sixweeks fescue was found unacceptable to cattle at all seasons and nitrogen fertilization did not increase its rooting strength or palatability. It contributed nothing to forage supply and interfered with cattle grazing of blue grama. Alternative practices for alleviating irregular grazing distribution include weed control or fertilization of infested areas to attract cattle.

Sixweeks fescue (Festuca octoflora Walt.) hinders the utilization of blue grama (Bouteloua gracilis (H.B.K.) Lag. ex Steud.) because cattle prefer areas most free of this annual grass. Hylton and Bement (1961) estimated a loss of about $\$ 25$ per head in 1958 when yearlings failed to graze infested upland areas. This is a ioss of $\$ 2$ to $\$ 3$ per acre based on the areas needing treatment.

Sixweeks fescue is scattered over Colorado at altitudes of 3500 to 8500 feet, and, in several varietal forms, is found throughout the United States (Harrington, 1954). On the Central Great Plains it is prevalent about once or twice in ten years, but its intermittently high abundance on some sites seriously disrupts management practices and reduces cattle gains. Consequently, ranchers requested consideration of the problems associated with this weed. Klipple and Costello (1960) reported sharp year

${ }^{1} A$ contribution of the Central Plains Experimental Range, Crops Research Division, Agricultural Research Service, U. S. Department of Agriculture, and Colorado Agricultural Experiment Station, Colorado State University, Fort Collins. Published with the approval of the Director, Colorado Agricultural Experiment Station, as Scientific Series Paper No. 944. to year fluctuations in fescue density under all grazing intensities. These stand fluctuations are related to weather and probably to soil and grazing differences. The seeds germinate in late summer or fall if high precipitation and cool temperatures prevail (Hylton and Bement, 1961).

Summer grazing extends from May 1 to November 1 on the Central Plains Experimental Range. Restricted grazing distribution becomes apparent in mid-season when the fescue matures and turns brown, but the seasonal nature of cattle rejection of infested areas is obscure. Headed plants are pulled easily with a ball of soil attached. Since cattle pull and drop many plants in the summer and fall, the attached soil is an obvious cause of cattle rejection. Odor, taste, and/ or texture also are suspected as causes of rejection because the cattle refrain from grazing blue grama where sixweeks fescue is abundant.

Several possible solutions need consideration. One might limit grazing to a specific season when sixweeks fescue is not objectionable to cattle, fertilize for stronger rooting and higher palatability of sixweeks fescue, control occurrences by proper grazing, or treat with an herbicide for chemical control. The best approach cannot be determined until the problem is better understood.

Consequently, this paper evaluates sixweeks fescue as a deterrent to the utilization of blue grama range. New information is given on the ecological occur- rence of sixweeks fescue by range sites, the effect of grazing intensity on fescue abundance, the seasonal extent of cattle rejection, and the effect of nitrogen fertilization and selectiveherbicide treatment on cattle preferences. A promising approach to problem alleviation is suggested.

\section{Methods \\ An area of Ascalon sandy loam} on the "plains upland" range site where cool temperatures and precipitation of 2.64 inches in September promoted the establishment of a thick stand of sixweeks fescue was selected in early October, 1961. A 3 by 6 strip-plot experiment was established in 3 replications including 3 cultural treatments and 6 grazing times. The cultural treatments were untreated check, ammonium nitrate at $40 \mathrm{lb}$ N/A applied surface broadcast in October, 1961, and simazine (2chloro-4, 6-bis-(ethylamine) -Striazine) at $3.5 \mathrm{lb} / \mathrm{A}$ active ingredient applied as a broadcast spray in October, 1961. Grazing times were May 10, May 25, June 7, June 27, August 2, and September 12, 1962. Cultural treatments were applied on plots 50 feet wide by 600 feet long eastwest, and were randomized in a latin-square arrangement among replications. Grazing times were assigned randomly to plots 100 feet wide by 150 feet long northsouth. Plots were isolated by electric cross fences to control grazing animals.

Yearling Hereford heifers were penned off feed on water overnight prior to experimental grazing. Three heifers were admitted in each replication at the first grazing time and six were admitted at other times. This number of animals accomplished moderate to heavy grazing on the most-preferred plot in 3 hours (approximately 9 a.m. to 12 noon). The heifers actually grazing were counted at 5-minute intervals. Since they were 
free to move back and forth among untreated, fertilized, and simazine-treated plots, the accumulated grazing observations evaluated cattle preferences among plots (Peterson, et al., 1958).

Species frequencies were sampled with an 8 by 8 -inch quadrat prior to grazing. The plots grazed on date 5 were sampled for herbage yields. Ten 1 by 2 -foot areas were hand clipped at ground level on each treatment plot on July 5, 1962. The herbage was weighed air dry to estimate yields.

Residual effects of cultural treatments were evaluated on June 18, July 9, and August 9, 1963.

To study fescue occurrence by range sites and grazing intensities, macroplots 100 by 75 feet were located on 53 different areas representing different range sites and different grazing intensities. Each macroplot was sampled in 1962 with 250 quadrats measuring 16 by 16 inches for the frequency of sixweeks fescue. Weather conditions were unsatisfactory for the establishment of sixweeks fescue in the fall, 1962, and the macroplots were not resampled in 1963.

Table 1. Species frequencies in 8 by 8 -inch quadrats by treatments.

\begin{tabular}{|c|c|c|c|}
\hline Species $^{1}$ & $\begin{array}{l}\text { Untreated } \\
\text { check }\end{array}$ & Nitrogen & Simazine \\
\hline & --- & (Percent) & $-\cdots-$ \\
\hline \multicolumn{4}{|l|}{ PERENNIALS: } \\
\hline Blue grama & $97 \pm 3^{2}$ & $98 \pm 1$ & $98 \pm 1$ \\
\hline Broad-leafed sedge & $14 \pm 6$ & $21 \pm 13$ & $16 \pm 6$ \\
\hline Plains pricklypear & $11 \pm 4$ & $10 \pm 3$ & $10 \pm 4$ \\
\hline Scarlet globemallow & $8 \pm 1$ & $6 \pm 2$ & $8 \pm 3$ \\
\hline Three-awn & $6 \pm 6$ & $2 \pm 1$ & $2 \pm 3$ \\
\hline Sand dropseed & $3 \pm 4$ & 1 & 1 \\
\hline \multicolumn{4}{|l|}{ ANNUALS: } \\
\hline Sixweeks fescue & $88 \pm 5$ & $94 \pm 3$ & $5 \pm 3$ \\
\hline Cryptantha & $5 \pm 2$ & $13 \pm 4$ & 1 \\
\hline Russian thistle & $2 \pm 2$ & $5 \pm 3$ & 0 \\
\hline
\end{tabular}

1.Thirty-four species with frequencies of $2 \%$ or less were omitted. Nomenclature follows Harrington (1954): Broad-leafed sedge (Carex heliophila Mack.), plains pricklypear (Opuntia polyacantha Haw.), three-awn (Aristida longiseta Steud.), sand dropseed (Sporobolus cryptandrus (Torr.) A. Gray), cryptantha (Cryptantha minima Rydb.) and Russian thistle (Salsola kali L.).

2 Means were computed from 1500 quadrat placements, and the data were treated as a normal distribution with 15 observations in the computation of confidence limits at the .05 probability level. appeared in nearly all species. Most of the annuals on simazine plots were dead. Scarlet globemallow (Sphaeralcea coccinea (Pursh) Rydb.) was turning yellow from simazine effectsbut blue grama was stimulated to produce longer leaves which appeared darker green than on untreated plots when viewed facing the sun and lighter green when facing away from the sun.

Sixweeks fescue was dry with seed shattering and blue grama was in anthesis on July 5 . The sixweeks fescue matured at about 5 inches tall on fertilized plots and about 3 inches on untreated ones.

Blue grama culms and heads obscured other vegetation by August 2 (especially on treated plots) and the dry sixweeks fescue was not readily apparent.

The herbage was all dry and brown by September 12, except that blue grama retained some green color near the soil on simazine-treated plots.

The sixweeks fescue pulled easily, and with soil attached, at all seasons. Nitrogen fertilization did not increase rooting strength.

Cattle Preferences.-Both nitrogen and simazine increased cattle preferences for the herbage produced (Figure 1). Averaged over all times and expressed in percent of total observations, the heifers preferred untreated, nitrogen, and simazine plots in the

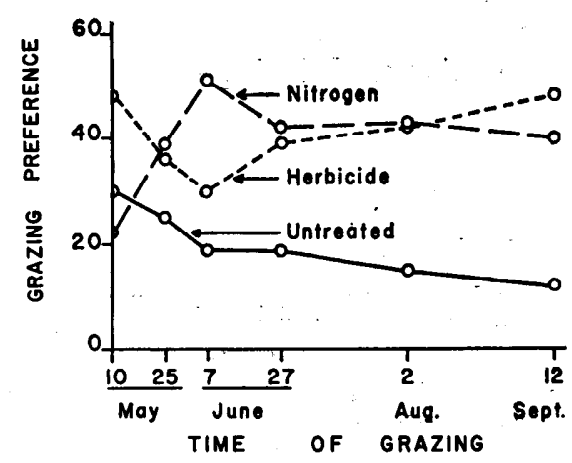

Ficure 1. Seasonal grazing preferences (percent of total observations) among untreated, nitrogen, and simazine plots (L.S.D. at $.01=15 \%$ ). 
proportions 20,40 , and $40 \%$, respectively (L.S.D. at .01 = 11\%). However, there were significant seasonal differences in the preferences expressed among treatments. Preferences for untreated plots declined as the season progressed, indicating a seasonal increase in the relative importance of the treatments. On May 10 the heifers preferred simazinetreated plots over untreated and untreated over fertilized ones. These preferences were negatively related to the frequency of occurrence of sixweeks fescue, which was only $1 / 4$ to $1 / 2$ inch tall.

Nitrogen fertilization imparted a little darker color to the herbage by May 25, when these plots were preferred as much as simazine-treated ones.

The blue grama on fertilized plots was much darker and taller by June 7, and the heifers preferred this herbage over that on simazine and untreated plots. The heifers grazed avidly on fertilized plots, but with a quick swing of the tongue, felt the herbage before each bite. Clumps of sixweeks fescue touched by the tongue were rejected by a quick side movement of the muzzle. Small fescue plants growing in blue grama clumps sometimes were pulled and eaten along with the blue grama. A few large fescue plants were pulled with a block of soil attached and dropped.

Effects of simazine on blue grama growth appeared by midJune. Subsequently, simazine and nitrogen plots were about equally preferred. Blue grama produced especially long, slender leaves on simazine plots. This growth characteristic, as well as the absence of sixweeks fescue, could account for improved cattle preferences. In the last 3 grazing trials, the heifers selected simazine-treated plots until the leafy growth was nearly gone, then turned to fertilized plots.

Herbage Yields.-Nitrogen fertilization increased the yields of
Table 2. Herbage yields on July 5 , 1962.

\begin{tabular}{lrrrr}
\hline & \multicolumn{4}{c}{$\begin{array}{c}\text { Herbage yields by } \\
\text { treatments }\end{array}$} \\
\cline { 2 - 6 } & $\begin{array}{c}\text { Un- } \\
\text { Nitro- Sima- } \\
\text { treated gen }\end{array}$ & zine & Mean \\
\hline Species & - & - (1b/A air dry) & -- \\
Blue & & & & \\
grama & 469 & 552 & 618 & $546 \pm 151$ \\
Sixweeks & & & & \\
fescue & 90 & 221 & 0 & $104 \pm 103$ \\
Others & 34 & 69 & 10 & $38 \pm 22$ \\
\hline Sum & 593 & 842 & 628 & $688 \pm 162$ \\
\hline
\end{tabular}

blue grama, six-weeks fescue, and "other species" by 18, 146, and $103 \%$, respectively (Table 2). Nitrogen increased total herbage $42 \%$ over the yields of untreated plots. Simazine increased blue grama yields $32 \%$, but eliminated annual herbs for only a $6 \%$ increase in total herbage over untreated plots. Counting all but sixweeks fescue, herbage yields were 503, 621, and 628 $\mathrm{lb} / \mathrm{A}$ on untreated, nitrogen, and simazine plots, respectively. Assuming that $200 \mathrm{lb} / \mathrm{A}$ of herbage remain when this range is completely utilized, net forage yields were about 300,420 , and $430 \mathrm{lb} / \mathrm{A}$ for untreated, nitrogen, and simazine plots, respectively. This indicates a net increase of $40 \%$ in usable forage that could give added value to the treatment of an area for uniform grazing distribution.

The increase in blue grama yields with nitrogen fertilization was small and not significant $(80 \mathrm{lb} / \mathrm{A})$ in this year of moderately favorable growing conditions. Simazine increased blue grama yields $150 \mathrm{lb} / \mathrm{A}$, but this response might have been due to physiological response as well as competition release.

Residual Effects in 1963.-Precipitation was lacking in the fall 1962 , and sixweeks fescue was extremely scarce in 1963. Mean preferences were 29,33 , and $38 \%$, respectively for untreated, simazine-treated, and fertilized plots, but these differences are not significant.

Mean frequencies of occurrence in 8 by 8 -inch quadrats in 1963 were essentially the same among treatments for all species except as follows: nitrogen fertilization increased the frequency of broad-leafed sedge from 10 to $23 \%$ and sixweeks fescue from 0 to $5 \%$, but simazine decreased scarlet globemallow from 10 to $4 \%$ as compared with untreated plots.

Herbage yields in 1963, being equal among treatments, averaged $566 \mathrm{lb} / \mathrm{A}$ of which $486 \mathrm{lb} / \mathrm{A}$ were blue grama.

Occurrence of Sixweeks Fescue.-Sixweeks fescue was found on all range sites in 1962 , but it was most frequent on the "plains upland' site (Table 3). On these upland soils the fescue was abundant in ungrazed exclosures

Table 3. Distribution of sixweeks fescue in 1962 by range sites and grazing intensities.

Grazing

Intensity 1

Trequency ${ }^{2}$ of sixweeks fescue by range sites:

\begin{tabular}{|c|c|c|c|c|c|}
\hline & & & & & \\
\hline & --1 & --- & (Percent) & $-1-$ & -- \\
\hline None & 1 & $54 \pm 3$ & 0 & $5 \pm 3$ & $7 \pm 3$ \\
\hline Light summer & - & $70 \pm 5$ & - & $24 \pm 5$ & $37 \pm 6$ \\
\hline Moderate summer & $31 \pm 3$ & $71 \pm 3$ & $4 \pm 1$ & $7 \pm 3$ & $72 \pm 5$ \\
\hline Heavy summer & $43 \pm 5$ & $60 \pm 3$ & 0 & 0 & $55 \pm 6$ \\
\hline Weighted mean & 26 & 66 & 2 & 11 & 49 \\
\hline $\begin{array}{l}\text { Number of } \\
\text { macroplots sampled }\end{array}$ & 14 & 21 & 7 & 6 & 5 \\
\hline
\end{tabular}

1 Grazing intensities practiced since 1939 .

2 Frequency of occurrence in 16-inch quadrats. We observed 250 quadrats in each macroplot. Confidence limits were interpolated from Snedecor, 1946, Table 1.1. 
as well as in range units grazed lightly, moderately, or heavily since 1939. Grazed areas on "sandy plains" and "salt meadow" had 5 to 40 times the frequency of fescue as ungrazed areas on the same sites. However, even where this annual grass could be considered an invader, the moderately-grazed areas were about equal to heavily-grazed units. In 1963, sixweeks fescue was extremely scarce on all sites and range units.

\section{Discussion and Conclusions}

Sixweeks fescue is unacceptable to cattle at all seasons, and nitrogen fertilization does not increase its rooting strength or palatability. This species contributes nothing to the forage supply but interferes with blue grama utilization. Alternative practices for alleviating irregular grazing distribution include weed control or fertilization of infested areas to attract cattle.

Weed control as a possible byproduct of good grazing practices is considered first. The "plains upland" range site where sixweeks fescue was most abundant is more extensive on the Central Great Plains than the other sites on this experimental range. But high frequencies of sixweeks fescue were found on this site even in exclosures left ungrazed since 1939. Therefore, this weed will not be controlled by reducing stocking rates. Fluctuating weather conditions will continue to produce sharp changes in fescue abundance unless cultural control practices are introduced.

Nitrogen fertilization increased sixweeks fescue frequency and yield, and decreased cattle preference in early May when blue grama growth was just beginning. Low preference in early May with the sixweeks fescue less than 1/2-inch tall could result from a disagreeable odor. This implication was partially substantiated by the total rejec- tion of hand-clipped samples offered to cattle in dry lot. Later in the season when blue grama was green and responding to nitrogen the fertilized plots were preferred over untreated and simazine plots. Thus, on a field basis, an application of ammonium nitrate limited to infested areas would prevent the rejection of them. This practice imposes limitations. Fertilization at a cost of about $\$ 6$ per acre would be necessary each year when fall weather promoted fescue establishment. Obviously, chemical control with lasting effects is needed.

Simazine was used to kill sixweeks fescue in this experiment, but other herbicides may provide equal control at less cost. Several herbicides will be compared in terms of effectiveness, cost and chemical residues because they cannot be used on a practical basis unless they leave the herbage free of residues and have to be approved for this purpose. Successful treatments will surely be developed. The emergence of sixweeks fescue in the fall when perennial grasses are dormant allows good selectivity and gives about 6 months for detection, treatment, and herbicide dissipation before spring grazing. The intermittent occurrence of sixweeks fescue will delay experimental progress.

\section{Summary}

Sixweeks fescue was evaluated as a deterrent to the utilization of blue grama by observing cattle preferences for plots untreated, fertilized with ammonium nitrate at $40 \mathrm{lb} \mathrm{N} / \mathrm{A}$, and treated with simazine at $3.5 \mathrm{lb} / \mathrm{A}$. Nitrogen increased sixweeks fescue and simazine killed it. Mean preferences were 20,40 , and $40 \%$ for untreated, nitrogen, and simazine plots, respectively, but preferences changed as the season progressed. Simazine plots were always highly preferred. Nitrogen plots were preferred less than untreated ones in early
May when blue grama growth was just beginning and equal to or more than simazine plots at later dates. Preferences for untreated plots decreased from $30 \%$ in May to $12 \%$ in September, indicating a seasonal gain in the deterrence associated with sixweeks fescue. Sixweeks fescue was unacceptable to cattle at all seasons, and nitrogen failed to increase its rooting strength or palatability. Yearling Hereford heifers rejected sixweeks fescue by staying away from infested plots, or by grazing carefully around the plants encountered.

Sixweeks fescue was most abundant on the "plains upland" range site, which is very extensive on the Central Great Plains. Range units on this site grazed at intensities of none, light, moderate, and heavy since 1939 all had high frequencies of sixweeks fescue in 1962. Therefore, this weed will not be controlled by reducing stocking rates. Fluctuating weather conditions will continue to produce sharp changes in fescue abundance unless cultural control practices are introduced. Several herbicides should be compared in terms of effectiveness, cost, and chemical residues to find one that can be approved for practical applications on blue grama range.

\section{LITERATURE CITED}

HaRRINGTON, H. D. 1954. Manual of the plants of Colorado. Sage Books, Denver.

Hylton, L. O., Jr., AND R. E. Bement. 1961. Effects of environment on germination and occurrence of sixweeks fescue. Jour. Range Mangt. 14: 257-261.

Klipple, G. E. AND D. F. Costello. 1960. Vegetation and cattle responses to different intensities of grazing on short-grass ranges on the Central Great Plains. U. S. Dept. Agr. Tech. Bul. 1216.

Peterson, R. G., P. H. Weswig, AND J. R. Cowan. 1958. Measuring palatability differences in tall fescue by grazing sheep. Agron. Jour. 15: 117-119.

SNedecor, George W. 1946. Statistical methods. 4th Ed. The Iowa State College Press, Ames. 